\title{
STRUCTURAL AND REACTIVITY ANALYSES OF 2-BENZYLAMINO-1,4-NAPHTHOQUINONE BY X-RAY CHARACTERIZATION, ELECTROCHEMICAL MEASUREMENTS, AND DFT SINGLE-MOLECULE CALCULATIONS
}

\author{
Silvio Cunha* \\ Instituto de Química, Universidade Federal da Bahia, Campus de Ondina, 40170-290 Salvador - BA / Instituto Nacional de Ciência \\ e Tecnologia em Energia e Ambiente, Universidade Federal da Bahia, Campus de Ondina, 40170-290 Salvador - BA, Brasil \\ Luis Fernandes P. Santos e Zênis N. Rocha \\ Instituto de Química, Universidade Federal da Bahia, Campus de Ondina, 40170-290 Salvador - BA, Brasil \\ Roberto Rivelino \\ Instituto de Física, Universidade Federal da Bahia, Campus de Ondina, 40170-290 Salvador - BA, Brasil \\ Jailton Ferrari \\ Departamento de Química, Centro de Ciências Exatas e da Natureza, Universidade Federal da Paraíba, Campus I, 58051-970 \\ João Pessoa - PB, Brasil \\ Ivo Vencato e Carlito Lariucci \\ Instituto de Física, Universidade Federal de Goiás, CP 131, 74001-970 Goiânia - GO, Brasil
}

Recebido em 30/6/10; aceito em 14/9/10; publicado na web em 27/10/10

\begin{abstract}
This study represents an integrated approach towards understanding the electronic and structural aspects of 2-benzylamino-1,4naphthalenedione, a representative 2-amino-napfthoquinone. To this end, theoretical calculations performed at the B3PW91/6-31+G(d) level of density functional theory, electrochemical and X-ray structural investigation were employed. Two intramolecular H-bonds and other two intermolecular H-bonds were observed, including non-classical interactions. Cyclic voltammogram (CV) and differential pulse voltammetry (DPV) show two pairs of peaks, being each one a monoelectronic process.
\end{abstract}

Keywords: enaminone; structural study; amino naphthoquinone.

\section{INTRODUCTION}

Functionalized 1,4-naphthoquinones is a theme of ongoing interest due to their potential in the synthesis of heterocyclic compounds ${ }^{1-4}$ as well as for their pharmacological applications. ${ }^{5-7}$ In this context, amino-naphthoquinones, which has embedded in their structure the $\mathrm{N}-\mathrm{C}=\mathrm{C}-\mathrm{C}=\mathrm{O}$ enaminone moiety, have been synthesized and tested for pharmacological activities. ${ }^{8-13}$ Among these chemical compounds, a particular bioactive derivative is the 2-benzylamino1,4-naphthoquinone $\mathbf{1}$, since this compound is a useful intermediate in the synthesis of densely substituted nitrogen heterocycles. ${ }^{2,14,15}$

Despite 1 has been described many years ago, new developments in its preparations have been reported, ${ }^{16,17}$ and considering its synthetic and biological applications, no structural study of such compound seems to be described in the literature. In this way, in our ongoing investigation on the chemistry of enaminones, ${ }^{18-22}$ we describe herein our results concerning the structural and reactivity analyses through $\mathrm{X}$-ray solid state characterization, electrochemical measurements, and employing density functional theory calculations for this substance.

\section{RESULTS AND DISCUSSION}

The 2-benzylamino-1,4-naphthoquinone 1 was prepared according to the known procedure, Figure $1 .{ }^{17}$ However, in ${ }^{1} \mathrm{H}$ NMR data obtained, the aromatic hydrogens were somewhat different in relation to the published chemical shifts of $\mathbf{1}$ and similar compounds. ${ }^{13}$ Thus, the multiplicity of the aromatic $\mathrm{ABCD}$ spin system was clearly defined as two triple doublets

\footnotetext{
*e-mail: silviodc@ufba.br
}

\#This work is dedicated to Prof. Hans Viertler, pioneer in electrochemistry applied to organic synthesis in Brazil, on the occasion of his $70^{\text {th }}$ birthday and two double double doublets (Figure 1S, supplementary material). To gain more insight into the structural aspects, single-crystals of $\mathbf{1}$ were obtained ${ }^{23}$ and the X-rays solid state study undertook (see Tables $1 \mathrm{~S}-6 \mathrm{~S}$, supplementary material). In this way, the structure of $\mathbf{1}$ was unambiguously confirmed, and two intramolecular $\mathrm{H}$-bonds were observed involving the atoms $\mathrm{N} 1-\mathrm{H} 1$...O $2\left[2.668(7) \AA, 105.7^{\circ}\right]$ and $\mathrm{C} 17-\mathrm{H} 17 \ldots$ N1 [2.921(10) $\left.\AA, 100.7^{\circ}\right]$, forming two pseudo planar five-membered rings, Figure 1, with a dihedral angle between these rings of $77.8(8)^{\circ}$. Additionally, there is one intermolecular $\mathrm{H}$-bond involving atoms N1H1...O1 $1^{\mathrm{i}}\left[2.882(8) \AA, 143.3^{\circ}\right.$, symmetry code: $\left.\mathrm{x}+1 / 2,-\mathrm{y}+1 / 2, \mathrm{z}+1\right]$, which links the molecules forming infinite one-dimensional chains along the directions $\left[\begin{array}{lll}1 & 0 & 2\end{array}\right]$ and $\left[\begin{array}{lll}-1 & 0 & 2\end{array}\right]$, Figure $2 S$, supplementary material. In a complementary way, one weak non-classical $\mathrm{H}$-bond $\mathrm{C} 10-\mathrm{H} 10 \ldots . . \mathrm{O} 2^{\mathrm{ii}}$ [3.307(9) $\AA, 158.6^{\circ}$, symmetry code: $\left.\mathrm{x}-1 / 2,-\mathrm{y}+1 / 2, \mathrm{z}\right]$ connects parallel neighboring chains, Figure $3 \mathrm{~S}$, supplementary material. This solid state study suggests that intermolecular interactions involving the benzyl moiety of 2-amino-naphthoquinone $\mathbf{1}$ do not play an important role in the conformational preference.

To gain insight into conformational bias, we undertook a conformational search for $\mathbf{1}$. Two energy minima were located after the B3PW91/6-31+G(d) conformational analysis around the C9-N1C11-C12 dihedral angle of 2-benzylamino-1,4-naphthalenedione. In this torsion path, the conformer 1a, which corresponds to the experimental solid-state structure, was obtained as a local minimum with a calculated dihedral angle of 76.8 degrees, corresponding to the synclinal orientation, while the conformer $\mathbf{1 b}$ was obtained as a global minimum, $0.87 \mathrm{Kcal} \mathrm{mol}^{-1}$ more stable than 1a, and dihedral angle of 176.7 degrees, which corresponds to the antiperiplanar conformation. The optimized structures for $\mathbf{1 a}$ and $\mathbf{1 b}$, and the calculated energy profile for this conformational analysis are given in Figure 2. As can be seen, the energy barrier for the interconversion 


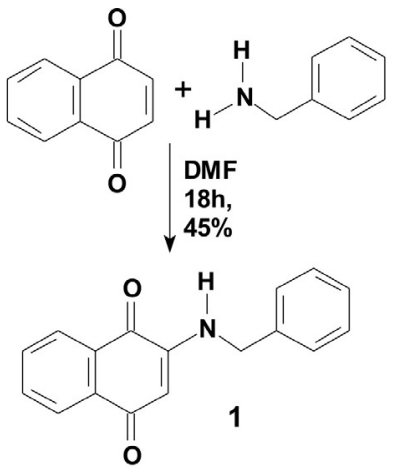

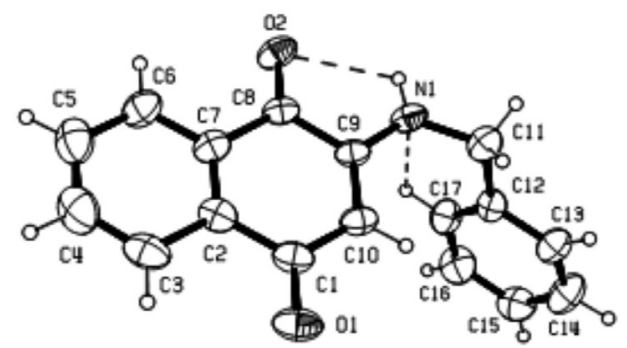

Figure 1. Synthesis and a labeled thermal ellipsoid plot of 2-benzylamino1,4-naphthoquinone with $30 \%$ probability surfaces

between the two conformers is only $1.4 \mathrm{Kcal} \mathrm{mol}^{-1}$. This result, in agreement with the X-ray study, indicates that the preference for the conformer 1a in the solid state is governed by the weak non-classical intramolecular H-bond $\mathrm{C} 17-\mathrm{H} 17$...N1, associated with weak forces of the packing interactions.

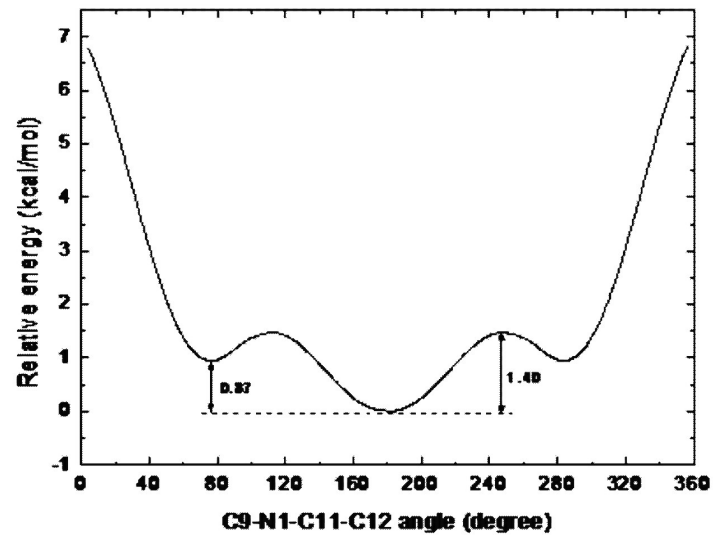

Figure 2. Calculated conformational analysis of 2-benzylamino-1,4naphthoquinone at the B3PW91/6-31+G(d) level around C9-N1-C11-C12 torsion angle

For purpose of comparison, the geometric parameters of $\mathbf{1}$ and $\mathbf{1 a}$ are listed in Table 1. The bond distances and angles of the solid-state structure of $\mathbf{1}$ and the corresponding calculated parameters for the optimized local minimum 1a agree satisfactorily. In addition, they are almost completely superimposable, as shown in Figure 4S, supplementary material, indicating a good agreement of dihedral angles.

Electrochemical parameters are important variables in the understanding of biological activity, especially in the class of quinones, ${ }^{13,24}$ and the association with theoretical calculations should be useful in understanding the reactivity behavior of polyfunctionalized compounds. ${ }^{25}$ Thus, to understand the electronic behavior of naphthoquinone 1, some theoretical and experimental parameters were investigated.
Table 1. Comparison of structural parameters of $\mathbf{1}$ and calculated conformer 1a obtained by X-ray and B3PW91/6-31+G(d) method, respectively

\begin{tabular}{|c|c|c|}
\hline Bond $(\AA)$ & X-ray & Calculated \\
\hline $\mathrm{O}(1)-\mathrm{C}(1)$ & $1.245(9)$ & 1.232 \\
\hline $\mathrm{O}(2)-\mathrm{C}(8)$ & $1.198(8)$ & 1.227 \\
\hline $\mathrm{N}(1)-\mathrm{C}(9)$ & $1.359(9)$ & 1.350 \\
\hline $\mathrm{N}(1)-\mathrm{C}(11)$ & $1.456(9)$ & 1.443 \\
\hline $\mathrm{C}(1)-\mathrm{C}(10)$ & $1.441(11)$ & 1.450 \\
\hline $\mathrm{C}(1)-\mathrm{C}(2)$ & $1.487(10)$ & 1.501 \\
\hline $\mathrm{C}(2)-\mathrm{C}(7)$ & $1.363(10)$ & 1.406 \\
\hline $\mathrm{C}(2)-\mathrm{C}(3)$ & $1.440(11)$ & 1.394 \\
\hline $\mathrm{C}(3)-\mathrm{C}(4)$ & $1.356(14)$ & 1.395 \\
\hline$C(4)-C(5)$ & $1.339(15)$ & 1.398 \\
\hline $\mathrm{C}(5)-\mathrm{C}(6)$ & $1.385(14)$ & 1.392 \\
\hline $\mathrm{C}(6)-\mathrm{C}(7)$ & $1.395(10)$ & 1.399 \\
\hline $\mathrm{C}(7)-\mathrm{C}(8)$ & $1.507(11)$ & 1.476 \\
\hline $\mathrm{C}(8)-\mathrm{C}(9)$ & $1.486(9)$ & 1.505 \\
\hline $\mathrm{C}(9)-\mathrm{C}(10)$ & $1.356(9)$ & 1.368 \\
\hline $\mathrm{C}(11)-\mathrm{C}(12)$ & $1.548(12)$ & 1.521 \\
\hline $\mathrm{C}(12)-\mathrm{C}(17)$ & $1.356(11)$ & 1.397 \\
\hline$C(12)-C(13)$ & $1.387(9)$ & 1.399 \\
\hline$C(13)-C(14)$ & $1.353(12)$ & 1.395 \\
\hline$C(14)-C(15)$ & $1.400(15)$ & 1.395 \\
\hline$C(15)-C(16)$ & $1.390(13)$ & 1.395 \\
\hline $\mathrm{C}(16)-\mathrm{C}(17)$ & $1.382(12)$ & 1.395 \\
\hline Angle (degree) & X-ray & Calculated \\
\hline $\mathrm{C}(9)-\mathrm{N}(1)-\mathrm{C}(11)$ & $124.7(6)$ & 124.9 \\
\hline $\mathrm{O}(1)-\mathrm{C}(1)-\mathrm{C}(10)$ & $121.5(7)$ & 121.9 \\
\hline $\mathrm{O}(1)-\mathrm{C}(1)-\mathrm{C}(2)$ & $120.0(7)$ & 120.1 \\
\hline $\mathrm{C}(10)-\mathrm{C}(1)-\mathrm{C}(2)$ & $118.5(6)$ & 118.0 \\
\hline $\mathrm{C}(7)-\mathrm{C}(2)-\mathrm{C}(3)$ & 119.1(7) & 119.5 \\
\hline $\mathrm{C}(7)-\mathrm{C}(2)-\mathrm{C}(1)$ & $121.2(7)$ & 120.8 \\
\hline $\mathrm{C}(3)-\mathrm{C}(2)-\mathrm{C}(1)$ & $119.5(7)$ & 119.7 \\
\hline $\mathrm{C}(4)-\mathrm{C}(3)-\mathrm{C}(2)$ & 116.7(9) & 120.1 \\
\hline $\mathrm{C}(5)-\mathrm{C}(4)-\mathrm{C}(3)$ & $124.8(10)$ & 120.4 \\
\hline $\mathrm{C}(4)-\mathrm{C}(5)-\mathrm{C}(6)$ & 119.2(9) & 119.9 \\
\hline$C(5)-C(6)-C(7)$ & $118.9(9)$ & 119.8 \\
\hline$C(2)-C(7)-C(6)$ & 121.3(8) & 120.3 \\
\hline $\mathrm{C}(2)-\mathrm{C}(7)-\mathrm{C}(8)$ & $120.2(6)$ & 120.1 \\
\hline $\mathrm{C}(6)-\mathrm{C}(7)-\mathrm{C}(8)$ & $118.5(7)$ & 119.6 \\
\hline $\mathrm{O}(2)-\mathrm{C}(8)-\mathrm{C}(9)$ & $121.9(7)$ & 119.1 \\
\hline $\mathrm{O}(2)-\mathrm{C}(8)-\mathrm{C}(7)$ & $121.5(6)$ & 123.0 \\
\hline $\mathrm{C}(9)-\mathrm{C}(8)-\mathrm{C}(7)$ & $116.6(5)$ & 117.9 \\
\hline $\mathrm{C}(10)-\mathrm{C}(9)-\mathrm{N}(1)$ & $124.6(6)$ & 126.3 \\
\hline $\mathrm{C}(10)-\mathrm{C}(9)-\mathrm{C}(8)$ & $122.0(7)$ & 120.9 \\
\hline $\mathrm{N}(1)-\mathrm{C}(9)-\mathrm{C}(8)$ & $113.3(5)$ & 112.8 \\
\hline $\mathrm{C}(9)-\mathrm{C}(10)-\mathrm{C}(1)$ & $121.4(7)$ & 122.2 \\
\hline $\mathrm{N}(1)-\mathrm{C}(11)-\mathrm{C}(12)$ & $112.1(7)$ & 115.3 \\
\hline
\end{tabular}


Table 1. Continuation

\begin{tabular}{lcc}
\hline Angle (degree) & X-ray & Calculated \\
\hline $\mathrm{C}(17)-\mathrm{C}(12)-\mathrm{C}(13)$ & $118.0(7)$ & 119.0 \\
$\mathrm{C}(17)-\mathrm{C}(12)-\mathrm{C}(11)$ & $125.0(6)$ & 121.5 \\
$\mathrm{C}(13)-\mathrm{C}(12)-\mathrm{C}(11)$ & $116.8(7)$ & 119.6 \\
$\mathrm{C}(14)-\mathrm{C}(13)-\mathrm{C}(12)$ & $121.9(9)$ & 120.7 \\
$\mathrm{C}(13)-\mathrm{C}(14)-\mathrm{C}(15)$ & $120.0(8)$ & 120.1 \\
$\mathrm{C}(16)-\mathrm{C}(15)-\mathrm{C}(14)$ & $118.4(8)$ & 119.6 \\
$\mathrm{C}(17)-\mathrm{C}(16)-\mathrm{C}(15)$ & $119.6(9)$ & 120.2 \\
$\mathrm{C}(12)-\mathrm{C}(17)-\mathrm{C}(16)$ & $122.0(8)$ & 120.5 \\
\hline
\end{tabular}

In this way, the calculated HOMO-LUMO for conformers $\mathbf{1 a}$ and $\mathbf{1 b}$ are shown in Figure 3. Curiously, the electronic profiles of the frontier molecular orbitals of the two calculated low-energy conformations of $\mathbf{1}$ are in contrast with the ones recently obtained for a glycine derivative.$^{26}$ However, our description of HOMO-LUMO orbitals are in accordance with the expected description of the HOMO-LUMO of the enaminone moiety. ${ }^{27,28}$ Moreover, the calculated HOMO's coefficients of $\mathbf{1}$ are in accordance with the observed regiochemistry of the ionic reaction between dimethyl acetylenedicarboxylate and 1, which afforded 4-quinolones instead of 2-quinolones. ${ }^{2}$
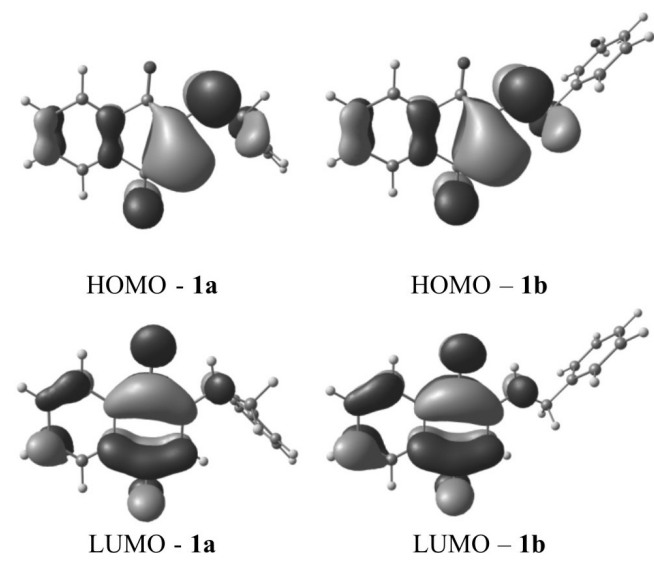

Figure 3. B3PW91/6-31+G(d) calculated HOMO and LUMO for conformers $\mathbf{I a}$ (optimized local minimum around the C9-N1 bond with dihedral angle C9-N1-C11-C12 = 76.76 degrees) and $\mathbf{1 b}$ (optimized global minimum around the C9-N1 bond with dihedral angle C9-N1-C11-C12 = 176.68 deg), showing the localization of the HOMO mainly on C10-N1 atoms, and the LUMO on the C8-O2 group

The two stable conformers present a low HOMO-LUMO energy gap (1a: $3.30 \mathrm{eV}, \mathrm{E}_{\text {номо }}-0.2363$, and $\mathrm{E}_{\text {Luмо }}-0.1152$ a.u.; 1b: $3.28 \mathrm{eV}$, $\mathrm{E}_{\text {номо }}-0.2339$, and $\mathrm{E}_{\text {LUмо }}-0.1134$ a.u.), which is in accordance with the soft ambiphilic behavior of enaminones. ${ }^{27,28}$ Additionally, the HOMO electronic density is localized mainly on $\mathrm{C} 10-\mathrm{N} 1$ atoms, also in accordance with the C-nucleophilic nature of such compounds. The LUMO is located mainly on C8-O2, suggesting a more electrophilic character for this carbonyl group than for $\mathrm{C} 1-\mathrm{O} 1$ carbonyl. This can be associated with the electronic nature of each carbonyl group. From a chemical point of view, C1-O1 carbonyl is more electron rich than C8-O2 carbonyl because the first has a strong extensive $\pi$ electrons conjugation with the electron releasing N1-benzyl group of the N1-C9-C10-C8 moiety, which justifies its smaller electron density in the LUMO.

The cyclic voltammogram (CV) and differential pulse voltammetry (DPV) of naphthoquinone 1 were obatined from -1.6 to +1.0 or
$+0.6 \mathrm{~V} \mathrm{vs} \mathrm{Ag} / \mathrm{AgCl}$ in acetonitrile solutions, and they show two pairs of peaks. In CV and DPV they occur $\mathrm{E}_{\mathrm{fl}}$ (arithmetic mean values of Epa1) at $-0.8 \mathrm{~V}$ and $\mathrm{E}_{\mathrm{f} 2}$ (arithmetic mean values of Epa1 and Epc1 values in $\mathrm{CV}$ ) at $-1.28 \mathrm{~V}$, being each one a monoelectronic process (Figure 5S, supplementary material) with a slightly shift in DPV (Figure 4). The first cathodic (Epc1) and anodic peaks (Epa1) can be assigned as a redox process, probably in $\mathrm{C} 8 \mathrm{-O} 2$ carbonyl.

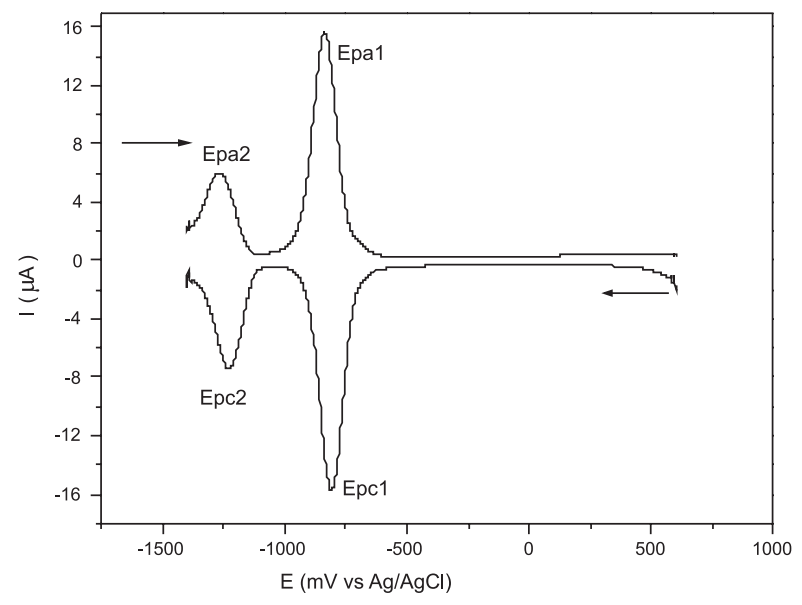

Figure 4. Differential pulse voltammograms of 1 in acetonitrile with $\mathrm{Bu}_{4} \mathrm{NBF}_{4}$ $\left(0.1 \mathrm{~mol} \mathrm{~L}^{-1}\right), v=36.6 \mathrm{mV} \mathrm{s}^{-1}$

\section{CONCLUSION}

This study represents an integrated approach towards understanding the electronic and structural aspects of a representative amino-naphthoquinone, the 2-benzylamino-1,4-naphthalenedione, using theoretical calculations, electrochemical and X-ray structural investigation of such compound, which could be useful in studies of reactivity as well as in the correlation of such properties with the potential biological applications of naphthoquinones, as has been described elsewhere..$^{10,12,13}$

\section{SUPLEMMENTARY MATERIAL}

${ }^{1} \mathrm{H}$ NMR spectrum of $\mathbf{1}$ and its additional X-ray details and characterization, differential pulse voltammetry curve, molecular absorption spectrum, and the colored HOMO/LUMO molecular orbital are available at http://quimicanova.sbq.org.br, with free access.

\section{EXPERIMENTAL}

Melting point was determined on a Microquímica MQAPF 301 hot plate apparatus and is uncorrected. NMR spectrum was obtained for ${ }^{1} \mathrm{H}$ at $300 \mathrm{MHz}$ using a Varian Gemini 300 spectrometer. Chemical shifts are reported in ppm units downfield from reference (internal TMS). Acetonitrile was refluxed for $6 \mathrm{~h}$ followed by distillation and kept under molecular sieves and tetrabutylammonium tetraflouroborate (Merck or Fluka) was purified through successive extractions with ethyl-acetate at $78^{\circ} \mathrm{C}$. Crystals were collected by filtration and vacuum dried.

\section{Synthesis of 2-benzylamino-1,4-naphthoquinone $1^{17}$}

To a solution of $1.00 \mathrm{~g}(6.32 \mathrm{mmol})$ of 1,4-naphtoquinone in 10 $\mathrm{mL}$ of DMF was added $1.47 \mathrm{~g}(13.72 \mathrm{mmol})$ of benzylamine and allowed to stand at room temperature with stirring for $18 \mathrm{~h}$. After this time, $70 \mathrm{~mL}$ of water was added and the solution was extracted with 
ethyl acetate $(3 \times 20 \mathrm{~mL})$. The organic layer was washed with brine $(10 \mathrm{~mL})$, dried over anhydrous $\mathrm{MgSO}_{4}$, filtered, and the solvent was evaporated. The residue was recrystallized from $\mathrm{EtOH}$ to afford 0.75 g of $\mathbf{1}$ (45\% yield) as an orange solid, mp 154.7-155.7 ${ }^{\circ} \mathbf{C}$ (lit. ${ }^{17} 160$ $161^{\circ} \mathrm{C}$ ). Slow evaporation of a solution of $\mathbf{1}$ in ethyl acetate afforded monocrystals. ${ }^{1} \mathrm{H}$ NMR $\left(\mathrm{CDCl}_{3}\right): 4.40(2 \mathrm{H}, \mathrm{d}, 5.7 \mathrm{~Hz}), 5.81(1 \mathrm{H}, \mathrm{s})$, $6.22(1 \mathrm{H}$, broad), 7.31-7.41 $(5 \mathrm{H}, \mathrm{m}), 7.63(1 \mathrm{H}, \mathrm{dt}, 1.2$ and $7.5 \mathrm{~Hz})$, $7.73(1 \mathrm{H}, \mathrm{dt}, 1.5$ and $7.5 \mathrm{~Hz}), 8.06(1 \mathrm{H}, \mathrm{ddd}, 0.6,1.2$ and $7.5 \mathrm{~Hz})$, $8.11(1 \mathrm{H}$, ddd, $0.6,1.5$ and $7.5 \mathrm{~Hz})$.

\section{Solid state structure}

Single crystals X-ray diffraction data were collected at room temperature using a Nonius CAD- 4 diffractometer ${ }^{29}$ with $\mathrm{CuK}$ radiation $(\lambda$ $=1.54180 \AA$ ) filtered through a graphite monochromator. The structures were solved by direct methods and refined anisotropically with fullmatrix least squares on $\mathrm{F}^{2}$ using the SHELXL97 suite of programs. ${ }^{30}$ The hydrogen atoms were placed at calculated positions and refined with riding constraints. The final least squares refinement converged to $R_{1}=0.0665$ and $w R_{2}=0.2428$ with 1339 unique reflections and 182 parameters. The crystallographic data were deposited at the Cambridge Crystallographic Data Center as CCDC deposition №. 782897. These data can be obtained free of charge from the Cambridge Crystallographic Data Centre via www.ccdc.cam.ac.uk/data_request/cif.

\section{Theoretical calculations}

The single-molecule calculations were carried out using the Gaussian 98 program. ${ }^{31}$ A relaxed potential energy surface (PES) scan was performed at the B3PW91 level of density functional theory, ${ }^{32}$ which employs Becke's three parameter functional ${ }^{33}$ combined with PerdewWang's 1991 gradient-corrected correlation functional..$^{34}$ The standard 6-31+G(d) basis set was used, giving a total of 406 Cartesian basis functions $(6 \mathrm{~d}, 7 \mathrm{f}) .{ }^{35}$ Thus, the geometry optimization for each point in the PES was performed at the B3PW91/6-31+G(d) level of calculation over a rectangular grid involving the selected C9-N1-C11-C12 dihedral angle of 2-benzylamino-1,4-naphthalenedione (Figure 1). The selected dihedral angle was 36 times stepped by increasing 10 degrees to obtain the energy profile for the conformational analysis of the isolated molecule. After obtaining the PES scan, the located energy minima were also fully optimized with the B3PW91/6-31+G(d) method.

\section{Electrochemistry}

The cyclic voltammetry and the differential pulse voltammetry measurements were taken with a potentiostat/galvanostat (PARC, model 273). All experiments were carried out using a conventional three electrodes cell. Platinum was used as working electrode. An Ag/ $\mathrm{AgCl}$ electrode was used as the reference electrode and a platinum wire as the auxiliary electrode. Electrochemical data were obtained using $0.1 \mathrm{~mol} \mathrm{~L}^{-1}$ solutions of tetrabutilammonium tetrafluoroborate $\left(\mathrm{Bu}_{4} \mathrm{NBF}_{4}\right)$ in acetonitrile as supporting electrolyte. In the cyclic voltammograms, neither anodic nor cathodic peaks were observed in the absence of 2-benzylamino-1,4-naphthalenedione in the potential range studied. All solutions were deaerated by bubbling high purity argon. Ferrocene $(+0.46 \mathrm{~V}$ versus $\mathrm{Ag} / \mathrm{AgCl})$, was employed as internal standard in acetonitrile solution. The reported formal potential $\left(\mathrm{E}_{\mathrm{f}}\right)$ values are the arithmetic mean of Epa and Epc values.

\section{ACKNOWLEDGMENTS}

The authors gratefully acknowledge the financial support of Conselho Nacional de Desenvolvimento Científico e Tecnológico
- CNPq, Coordenação de Aperfeiçoamento de Pessoal de Nível Superior - CAPES, and Fundação de Amparo à Pesquisa do Estado da Bahia - FAPESB. We thank CENAPAD-SP for the use of computer facilities. We also thank CNPq for research fellowships to Z. N. Rocha, C. Lariucci, I. Vencato, R. Rivelino and S. Cunha.

\section{REFERENCES}

1. Fieser, L. F.; Fieser, M.; J. Am. Chem. Soc. 1948, 70, 3215.

2. Pinto, A. V.; Ferreira, V. F.; Pinto, M. C. F. R.; Mayer, L. U.; Synth. Commun. 1985, 15, 1181.

3. Ribeiro, C. M. R.; de Souza, P. P.; Ferreira, L. L. D. M.; Pinto, L. A.; de Almeida, L. S.; de Jesus J. G.; Quim Nova 2008, 31, 759.

4. Camara, C. A.; Pinto, A. C.; Rosa, M. A.; Vargas, M. D.; Tetrahedron 2001, 57, 9569 .

5. da Silva Júnior, E. N.; de Deus, C. F.; Cavalcanti, B. C.; Pessoa, C.; Costa-Lotufo, L. V.; Montenegro, R. C.; de Moraes, M. O.; Pinto, M. C. F. R.; de Simone, C. A.; Ferreira, V. F.; Goulart, M. O. F.; Andrade, C. K. Z.; Pinto, A. V.; J. Med. Chem. 2010, 53, 504.

6. Pinto, A. V.; Pinto, M. C. F. R.; de Oliveira, C. G. T.; An. Acad. Bras. Cienc. 1982, 54, 107.

7. Oliveira, C. G. T.; Frederico, F. M.; Ferreira, V, F.; Freitas, C. C.; Rabello, R. F.; Carballido, J. M.; Corra, L. C. D.; J. Braz. Chem. Soc. 2001, 12, 339 .

8. da Silva, A. J. M.; Netto, C. D.; Pacienza-Lima, W.; Torres-Santos, E. C.; Rossi-Bergmann, B.; Maurel, S.; Alexis Valentin, A.; Costa, P. R. R.; J. Braz. Chem. Soc. 2009, 20, 176.

9. Plyta, Z. F.; Li, T.; Papageorgiou, V. P.; Mellidis, A. S.; Assimopoulou, A. N.; Pitsinos, E. N.; Couladouros, E. A.; Bioorg. Med. Chem. Lett. 1998, 8,3385 .

10. da Silva Junior, E. N.; de Moura, M. A. B. F.; Pinto, A. V.; Pinto, M. C. F. R.; de Souza, M. C. B. V.; Araujo, A. J.; Pessoa, C.; Costa-Lotufo, L. V.; Montenegro, R. C.; de Moraes, M. O.; Ferreira, V. F.; Goulart, M. O. F.; J. Braz. Chem. Soc. 2009, 20, 635.

11. da Silva Junior, E. N.; de Souza, M. C. B. V.; Fernandes, M. C.; MennaBarreto, R. F. S.; Pinto, M. C. F. R.; Lopes, F. A.; de Simone, C. A.; Andrade, C. K. Z.; Pinto, A. V.; Ferreira, V. F.; de Castro, S. L.; Bioorg. Med. Chem. 2008, 16, 5030.

12. da Silva Junior, E. N.; de Souza, M. C. B. V.; Pinto, A. V.; Pinto, M. C. F. R.; Goulart, M. O. F.; Pessoa, C.; Costa-Lotufo, L.; Montenegro, R. C.; Moraes, M. O.; Ferreira, V. F.; Bioorg. Med. Chem. 2007, 15, 7035.

13. Francisco, A. I.; Casellato, A.; Neves, A. P.; Carneiro, J. W. M; Vargas, M. D.; Visentin, L. C.; Magalhães, A.; Câmara, C. A.; Pessoa, C.; CostaLotufo, L. V.; Marinho Filho, J. D. B.; Moraes, M. O.; J. Braz. Chem. Soc. 2010, 21, 169.

14. Silva, T. M. S.; Camara, C. A.; Barbosa, T. P.; Soares, A. Z.; da Cunha, L. C.; Pinto, A. C.; Vargas, M. D.; Bioorg. Med. Chem. 2005, 13, 193.

15. Camara, C. A.; Silva, T. M. S.; Da-Silva, T. G.; Martins, R. M.; Barbosa, T. P.; Pinto, A. C.; Vargas, M. D.; An. Acad. Bras. Cienc. 2008, 80, 329.

16. Komei, M.; Nisaburo, I.; Daiji, M.; Yakugaku Zasshi 1953, 73, 961.

17. Aristoff, P. A.; Jonhson, P. D.; J. Org. Chem. 1992, 57, 6234.

18. Cunha, S.; Damasceno, F.; Ferrari, J.; Tetrahedron Lett. 2007, 48, 5795.

19. Cunha, S.; Bastos, R. M.; Silva, P. O.; Costa, G. A. N.; Vencato, I.; Lariucci, C.; Napolitano, H. B.; Oliveira, C. M. A.; Kato, L.; Silva, C. C.; Menezes, D.; Vannier-Santos, M. A.; Monatsh. Chem. 2007, 138, 111.

20. Cunha S.; Silva, V. C.; Napolitano, H. B.; Lariucci, C.; Vencato, I.; J. Braz. Chem. Soc. 2003, 14, 107.

21. Cunha, S.; Rodovalho, W.; Azevedo, N.; Mendonça, M. O.; Lariucci, C.; Vencato, I.; J. Braz. Chem. Soc. 2002, 13, 629.

22. Cunha, S.; Kascheres, A.; J. Braz. Chem. Soc. 2001, 12, 481.

23. Cunha, S.; Quim Nova 2008, 31, 906. For other solid state study of 2-amino-naphthoquinone derivatives see: Singh, M. W.; Karmakar, A.; Barooah, N.; Baruah, J. B.; Beilstein J. Org. Chem. 2007, 3, No. 10. 
24. Abreu, F. C.; Ferraz, P. A. L.; Goulart, M. O. F.; J. Braz. Chem. Soc. 2002, 13, 19; Ferreira, D. C. M.; Goulart, M. O. F.; Moreira, M. S. A.; Pinto, A. V.; Tapsoba, I.; Arbault, S.; Amatore, C.; ChemBioChem 2009, 10,528 .

25. Cunha, S.; Rocha, Z. N.; Quim Nova 2008, 31, 788.

26. Valente, C.; Moreira, R.; Guedes, R. C.; Iley, J.; Jaffarc, M.; Douglas, K. T.; Bioorg. Med. Chem. 2007, 15, 5340.

27. Eberlin, M. N.; Takahata,Y.; Kascheres, C.; J. Org. Chem. 1990, 55, 5150 .

28. Kascheres, A.; Correa Filho, J.; Cunha, S.; Tetrahedron 1993, 49, 381.

29. Enraf-Nonius CAD-4/PC. Version 1.2; Enraf-Nonius, Delft, The Netherlands, 1993.

30. Sheldrick, G. M.; Acta Cryst. 2008, A64, 112.

31. Gaussian 03, Revision D.01; Frisch, M. J.; Trucks, G. W.; Schlegel, H. B.; Scuseria, G. E.; Robb, M. A.; Cheeseman, J. R.; Montgomery, Jr., J. A.; Vreven, T.; Kudin, K. N.; Burant, J. C.; Millam, J. M.; Iyengar, S. S.; Tomasi, J.; Barone, V.; Mennucci, B.; Cossi, M.; Scalmani, G.; Rega, N.; Petersson, G. A.; Nakatsuji, H.; Hada, M.; Ehara, M.; Toyota, K.;
Fukuda, R.; Hasegawa, J.; Ishida, M.; Nakajima, T.; Honda, Y.; Kitao, O.; Nakai, H.; Klene, M.; Li, X.; Knox, J. E.; Hratchian, H. P.; Cross, J. B.; Bakken, V.; Adamo, C.; Jaramillo, J.; Gomperts, R.; Stratmann, R. E.; Yazyev, O.; Austin, A. J.; Cammi, R.; Pomelli, C.; Ochterski, J. W.; Ayala, P. Y.; Morokuma, K.; Voth, G. A.; Salvador, P.; Dannenberg, J. J.; Zakrzewski, V. G.; Dapprich, S.; Daniels, A. D.; Strain, M. C.; Farkas, O.; Malick, D. K.; Rabuck, A. D.; Raghavachari, K.; Foresman, J. B.; Ortiz, J. V.; Cui, Q.; Baboul, A. G.; Clifford, S.; Cioslowski, J.; Stefanov, B. B.; Liu, G.; Liashenko, A.; Piskorz, P.; Komaromi, I.; Martin, R. L.; Fox, D. J.; Keith, T.; Al-Laham, M. A.; Peng, C. Y.; Nanayakkara, A.; Challacombe, M.; Gill, P. M. W.; Johnson, B.; Chen, W.; Wong, M. W.; Gonzalez, C.; Pople, J. A.; Gaussian, Inc., Wallingford CT, 2004.

32. Koch, K.; Holthausen, M. C.; A Chemists Guide to Density Functional Theory, Wiley-VCH: Weinheim, 2001.

33. Becke, A. D.; J. Chem. Phys. 1993, 98, 5648.

34. Perdew, J. P.; Wang, Y.; Phys. Rev. B 1992, 45, 13244.

35. Hehre, W. J.; Radom, L.; Schleyer, P. R.; Pople, J. A.; Ab Initio Molecular Orbital Theory, Wiley: New York, 1986, chap. 4. 